\title{
Detection and Quantification of Pythium tracheiphilum in Soil by Multiplex Real-Time qPCR
}

\author{
Hervé Van der Heyden, ${ }^{1, \dagger}$ Thérèse Wallon, ${ }^{1}$ C. André Lévesque, ${ }^{2}$ and Odile Carisse ${ }^{3}$ \\ ${ }^{1}$ Compagnie de recherche Phytodata, Sherrington, QC JOL 2N0, Canada; ${ }^{2}$ Ottawa Research and Development Research Centre, \\ Agriculture and Agri-Food Canada, Ottawa, ON K1A 0C6, Canada; and ${ }^{3}$ Saint-Jean-sur-Richelieu Research and Development \\ Centre, Agriculture and Agri-Food Canada, Saint-Jean-sur-Richelieu, QC J3B 3E6, Canada
}

\begin{abstract}
In Canada, head lettuce (Lactuca sativa capitata) is extensively produced in the muck soils of southwestern Québec. However, yields are increasingly affected by various soilborne pathogens, including Pythium spp., which cause wilt and damping off. In a survey conducted in Québec muck soils in 2010 and 2011, Pythium tracheiphilum Matta was identified as the predominant Pythium sp. in the root of head lettuce showing Pythium stunt symptoms. Therefore, to improve risk assessment and help further understanding of disease epidemiology, a specific and sensitive real-time quantitative polymerase chain reaction (qPCR) assay based on TaqMan-minor groove binder (MGB) technology was developed for $P$. tracheiphilum. The PCR primers along with a TaqMan-MGB probe were designed from the ribosomal internal transcribed spacer 2 region. A 100-bp product was amplified by PCR from all P. tracheiphilum

isolates tested while no PCR product was obtained from 38 other Pythium spp. or from a selection of additional lettuce pathogens tested. In addition to $P$. tracheiphilum, the assay was multiplexed with an internal control allowing for the individual validation of each PCR. In artificially infested soils, the sensitivity of the qPCR assay was established as 10 oospores/g of dry soil. P. tracheiphilum was not detected in soils in which lettuce has never been grown; however, inoculum ranged from 0 to more than 200,000 oospores/g of dry soil in commercial lettuce fields. Also, disease incidence was positively correlated with inoculum concentration $(r=$ 0.764). The results suggest that inoculum concentration should be considered when making Pythium stunt management decisions. The developed qPCR assay will facilitate reliable detection and quantification of $P$. tracheiphilum from field soil.
\end{abstract}

In North America, just over 100,000 ha of land are dedicated to head lettuce (Lactuca sativa capitata) production annually (FAO 2017). In Canada, $86 \%$ of this production is concentrated in Québec muck soils (Statistics Canada 2017). Lettuce is grown from midApril to mid-October, with one to three harvests annually. Typical crop rotations comprise three to five lettuce crops every 3 years. During the growing season, average air temperatures are below $21^{\circ} \mathrm{C}$ while average precipitation is about $85 \mathrm{~mm} / \mathrm{month}$. Under these conditions, soilborne diseases represent a major constraint for this production. Among these diseases, the most prevalent include bottom rot caused by Rhizoctonia solani, lettuce drop caused by Sclerotinia sclerotiorum and $S$. minor, and lettuce stunt and wilt caused by Pythium spp. (Blancard et al. 2003).

Annual lettuce yield losses associated with Pythium spp.-induced diseases can be significant because disease incidence can be up to 50\% (Coplin et al. 1980). Several Pythium spp. affect a wide range of cultivated native plants, causing root rot, wilt, and damping-off (Hendrix and Campbell 1973). When diagnosed in the field, the problem is frequently associated with a Pythium sp. and reported without the identification of the species involved. However, up to 14 Pythium spp. have been reported to be pathogenic to field lettuce (Blancard et al. 2003). Among these, Pythium tracheiphilum Matta was first identified in 1965 to cause lettuce stem rot and vascular

${ }^{\dagger}$ Corresponding author: Hervé Van der Heyden;

E-mail: hvanderheyden@phytodata.ca

Funding: For the first part of this work, funding was provided, in part, by Agriculture and Agri-Food Canada through the Canadian Agricultural Adaptation Program (CAAP). The second part of this project was carried out under the Prime-Vert-3.2 (2013-2018) program and received financial assistance from the Ministère de l'Agriculture, des Pêcheries et de l'Alimentation (MAPAQ) through the Green Fund.

Accepted for publication 4 September 2018.

This article is in the public domain and not copyrightable. It may be freely reprinted with customary crediting of the source. The American Phytopathological Society, 2019. necrosis (Matta 1965). It was later identified in the Netherlands to be highly pathogenic to lettuce (Blok and van der Plaats-Niterink 1978) and subsequently reported in North America, the United Kingdom, and Australia (Hall 1989; Kumar et al. 2007; Nordskog et al. 2008). This is one of the very few Pythium spp. with a very narrow host range and is on the quarantine list of certain countries. Infected plants are characteristically smaller, contrasting with healthy adjacent plants, and their leaves are yellow and wilted. At the earliest stage, wilting arises during the warmest period of the day while the plants recover during the night (Blancard et al. 2003). Thereafter, the symptoms become irreversible, leading to plant desiccation and death. The taproot of infected plants is often misshapen, rough, discolored, and lacking in secondary rootlets (Blancard et al. 2003). A longitudinal section of infected taproots reveals dark vascular tissues with grayblack streaks, while remaining rootlets show honey-brown lesions.

In conventional lettuce production, the control of Pythium spp.induced diseases can be achieved using chemical fungicides. In Canada, lettuce seed are typically treated with metalaxyl, while transplants are treated with a soil-drench application of cyazofamid prior to transplantation. In addition to this systematic chemicalbased approach, biological control agents (BCAs) have been shown to be efficient under specific conditions. Although biopesticides still occupy a small share of the global pesticide market (5\%), this segment is growing fast, at a rate of about $8 \%$ a year (Olson 2015). It was shown that BCAs can act according to at least four modes of action: competition, parasitism, antibiosis, and induced resistance (Bélanger et al. 2012). As an example of competition and mycoparasitsm, species of the genus Trichoderma have been shown to efficiently control damping-off caused by Pythium spp. (El-Katatny et al. 2006; Paulitz et al. 1990) while Gliocladium virens could control P. ultimum in zinnia, cotton, and cabbage (Lumsden and Locke 1989). Because of their ability to produce a wide variety of antibiotics and secondary metabolites, species of the Streptomyces genus were also reported as potential BCAs (Yuan and Crawford 1995). Streptomyces lydicus showed in vitro inhibition activity against $P$. dissotocum, $P$. irregulare, $P$. aff. macrosporum, $P$. mamillatum, $P$. aff. oopapillum, $P$. rostratifingens, $P$. sylvaticum, and $P$. ultimum isolated from forest nursery crops (Weiland 2014). This potential BCA 
was as efficient as the commercial standard mefenoxam on $P$. aphanidermatum, $P$. irregulare, and $P$. ultimum affecting geranium and snapdragon in a greenhouse trial (Múnera and Hausbeck 2015). However, under field conditions, reaching reproducible and consistent control of soilborne diseases with BCAs is often limited (Kilany et al. 2015; Weiland 2014). Weiland (2014) suggested that Pythium population diversity may influence effectiveness of BCAs. Hence, the accurate identification and precise quantification of a given pathogen could improve the efficiency of BCA-based control strategies.

The identification of Pythium from soil samples traditionally requires the use of dilution plating on selective media combined with morphological observations of isolated structures (Conway 1985; Jeffers and Martin 1986; Lumsden et al. 1975). However, there are significant similarities between morphological traits of the asexual structure of some Pythium spp. which makes the identification labor intensive and often inaccurate. Moreover, subsequent DNA sequencing is often needed to confirm Pythium identity for species that are very difficult to differentiate (e.g., strains not producing sporangia). The internal transcribed spacer (ITS) and cytochrome $c$ oxidase subunit I (COI) DNA regions are extensively used as DNA barcodes for species identification and phylogeny analysis (LéVesque and De Cock 2004; Robideau et al. 2011). The ITS region has also been used for the development of specific markers allowing the identification and quantification of Pythium spp. in soil (Cullen et al. 2007; Kernaghan et al. 2008; Schroeder et al. 2006). However, the development of such molecular quantification tools requires particular attention toward the presence of potential polymerase chain reaction (PCR) inhibitors (humic acid, clay, and so on), especially in soil with high organic-matter content (Deora et al. 2015).

The availability of a reliable and sensitive real-time quantitative PCR (qPCR) assay for the detection and quantification of P. tracheiphilum in soil samples would be of benefit to growers and crop specialists, providing a better assessment of risk prior to planting and for selection of the most appropriate control method. Therefore, the objectives of our study were twofold: (i) to survey the Pythium sp. diversity in soils dedicated to the production of lettuce and (ii) to develop a real-time multiplex qPCR assay for $P$. tracheiphilum that includes an internal control (IC).

\section{Materials and Methods}

Pythium sp. from lettuce root and root rhizosphere. Study location and sampling. In 2010 and 2011, 128 samples were collected in 32 fields from Québec muck land area located $50 \mathrm{~km}$ southwest of Montreal $\left(73^{\circ} 24^{\prime}\right.$ to $73^{\circ} 37^{\prime}$ West, $45^{\circ} 10^{\prime}$ to $45^{\circ} 16^{\prime}$ North). Fields were selected based on the presence of lettuce wilt or root rot symptoms. In each location, roots of infected plants were collected individually and corresponding soil samples, composed of approximately $250 \mathrm{~g}$ of soil, were taken in the first $15 \mathrm{~cm}$ within the rhizosphere of infected plants. Samples were collected between June and September of each year at a growth stage between 12 and 20 leaves. After sampling, soil samples were stored at $4{ }^{\circ} \mathrm{C}$ for a maximum of $24 \mathrm{~h}$, prior to weighing, drying, and homogenization.

DNA extraction. Soil samples were air dried at room temperature and a subsample of $100 \mathrm{~g}$ of dried soil was homogenized with a mortar and pestle. Total DNA was extracted from $0.2 \mathrm{~g}$ of dry soil using the Fast DNA spin kit for soil (MP Biomedicals, Solon, $\mathrm{OH})$. Lettuce root tips and root taps were surface sterilized with $1 \%$ sodium hypochlorite and rinsed twice with distilled water prior to DNA extraction. DNA was extracted from root tissues using the FastDNA Spin Kit (MP Biomedicals) with the CLS-VF buffer required for DNA extraction from infected plant tissues. Finally, DNA extraction from mycelium of Pythium spp. cultures was performed with the FastDNA Spin Kit with the CLS-Y buffer. All types of samples were homogenized in a FastPrep-24 instrument for $40 \mathrm{~s}$ at a speed setting of 6.0. For plant tissue and mycelium, final DNA elution was performed using $100 \mu \mathrm{l}$ of the provided elution buffer whereas, for soil samples, only $50 \mu$ l of the manufacturer's elution buffer was used. In all cases, the elution buffer was preheated at $55^{\circ} \mathrm{C}$.

Detection of Pythium spp. by DNA array hybridization. PCR amplification of the ITS sequence region and digoxigenin (DIG) labeling were performed using the universal primers UN-up18S42 and Oomlo28S-345H (Tambong et al. 2006) (Table 1). The Titanium Taq PCR kit (Clonetech Laboratories Inc., Mountain View, CA, USA) was used in a $25-\mu 1$ reaction volume containing $1 \times$ titanium buffer, $0.15 \mathrm{mM}$ DIG-dNTP, $0.5 \mu \mathrm{M}$ each primer, and $1 \times$ titanium Taq DNA polymerase. Macroarrays used for DNA hybridization and detection were prepared following the protocol described by Tambong et al. (2006). In summary, membranes were prehybridized in $1 \%$ skim milk buffer for $1.5 \mathrm{~h}$ at $54^{\circ} \mathrm{C}$. DIG-labeled amplicons were added to $7.5 \mathrm{ml}$ of hybridization buffer and denatured in boiling water, and the prehybridized membrane were transferred to tubes containing the labeled amplicons. Hybridization was performed overnight at $54^{\circ} \mathrm{C}$, membrane was washed twice at $54^{\circ} \mathrm{C}$ for $45 \mathrm{~min}$ with a stringency buffer $(0.1 \%$ sodium dodecyl sulfate, $0.9 \mathrm{M} \mathrm{NaCl}$, and $0.09 \mathrm{M} \mathrm{Na}$ citrate) and DIG was revealed by chemiluminescence using CDP-Star (Sigma-Aldrich, St. Louis) (Fessehaie et al. 2003).

Development of a $P$. tracheiphilum-specific assay. Pythium spp. isolates. All isolates used for the development of the Taqman qPCR assay are listed in Table 2. Most of the Pythium spp. used in this study were collected in 2015 and 2016 in commercial fields while the rest of the isolates were obtained from the Canadian National Mycological Herbarium (DAOM) and from the Québec diagnostic laboratory (Laboratoire de diagnostique en Phytoprotection, Ministère de l'Agriculture, des Pêcheries et de l'Alimentation, Québec City, QC, Canada). To isolate Pythium spp. from diseased tissues, roots of infected plants were surfaced sterilized with $1 \%$ sodium hypochlorite, washed twice with distilled water, air dried, and placed on water agar for 24 to $48 \mathrm{~h}$. After incubation, coenocytic hyphae were transferred onto new plates containing potato dextrose agar for purification. This step was repeated until a pure culture was obtained. Finally, mycelium present on the edge of the plate was used for DNA extraction following the procedure described previously.

DNA extraction and ITS sequencing. In total, $500 \mathrm{mg}$ of fresh mycelium was used for DNA extraction with the Fast DNA Spin Kit following the recommended procedure. The concentration and quality of each purified DNA sample was estimated with a Nano-Drop lite spectrophotometer (Thermo Scientific, Mississauga, ON, Canada)

Table 1. Primers and probes used in this study

\begin{tabular}{lll}
\hline Primer or probe & \multicolumn{1}{c}{$\mathbf{5}^{\mathbf{\prime}} \mathbf{- \mathbf { 3 } ^ { \prime } \text { Nucleotide sequence }}$} & \multicolumn{1}{c}{ Reference } \\
\hline UN-up18S42 & CGTAACAAGGTTTCCGTAGGTGAAC & Tambong et al. 2006 \\
Oom-lo28S-345H & ACTTGTTCGCTATCGGTCTCGCA & $\ldots$ \\
ITS-1 & TCCGTAGGTGAACCTGCGG & $\ldots$ \\
ITS-4 & TCCTCCGCTTATTGATATGC & $\ldots$ \\
909F & AGGCAAATGGTTATTGTGTAGTAGAAT & This study \\
PTMGBP & 6-FAM-CGGAGATGACTGTGCG-MGB & $\ldots$ \\
PTMGBR & CAAATCGGTGTTGCCTTCTCTAC & $\ldots$ \\
EIPC100F & AGGCTAGCTAGGACCGATCAATAGG & $\ldots$ \\
EIPC100P & FAM-CCTATGCGTTCCGAGGTGACGACCTTGCC-IBHQ1 & Fall et al. 2015 \\
EIPC100R & AGTGCTTCGTTACGAAAGTGACCTTA & $\ldots$ \\
\hline
\end{tabular}

${ }^{\mathrm{a}} \mathrm{FAM}=$ fluorescein, $\mathrm{MGB}=$ minor groove binder, and $\mathrm{BHQ}=$ black hole quencher. 
and DNA concentration was adjusted to $10 \mathrm{ng} / \mu \mathrm{l}$. The ITS region from ribosomal DNA (rDNA) was amplified for each collected isolate using the universal ITS1/ITS4 primers (Table 1) (White et al. 1990). The amplification mix contained $500 \mathrm{nM}$ each primer, $5 \mu 1$ of template DNA, and the Phusion High-Fidelity PCR Master Mix with HF buffer (New England Biolab, Ipswich, MA). The PCR cycling conditions were set at $98^{\circ} \mathrm{C}$ for $2 \mathrm{~min} ; 35$ cycles at $98^{\circ} \mathrm{C}$ for $10 \mathrm{~s}, 60^{\circ} \mathrm{C}$ for $15 \mathrm{~s}$, and $72^{\circ} \mathrm{C}$ for $30 \mathrm{~s}$; and a final extension step at $72^{\circ} \mathrm{C}$ for $10 \mathrm{~min}$. PCR products were purified using the QIAquick PCR purification kit (Qiagen, Toronto, ON, Canada) and sent to the Centre de Recherche du CHUL/ CHUQ at Laval University to be sequenced with both ITS1 and
ITS4 primers. Each DNA sequence was visualized in Genious 9.1.3 and manually edited. In total, 89 Pythium sp. isolates were sequenced and sequences obtained in this project were deposited into GenBank under accession numbers MH023325 to MH023389. Neighborjoining tree analysis of the ITS- 2 region was performed using the Tamura-Nei substitution model with 100 bootstraps (Geneious V9.1.5) to show sequence homogeneity among $P$. tracheiphilum isolates and to identify the closest relative species. Among the 89 isolates sequenced in this study, a set of 65 isolates was used for the design of the real-time TaqMan-minor groove binder (MGB) assay while the remaining 24 isolates were kept for validation purposes (Table 2).

Table 2. Isolates of Pythium sp. and other plant pathogens used for the validation of the Pythium tracheiphilum TaqMan-minor groove binder (MGB) assay evaluated at a DNA concentration of $1 \mathrm{ng}^{\mathrm{a}}$

\begin{tabular}{|c|c|c|c|c|c|}
\hline Isolate & Species & Clade & Host & ITS1/ITS4 & 909F/PTMGB-P/PTMGB-REV \\
\hline BR0899b & P. tracheiphilum & B & Lactuca sativa & + & 22.34 \\
\hline BR0931 b & P. tracheiphilum & B & L. sativa & + & 22.45 \\
\hline BR0932 $2^{b}$ & P. tracheiphilum & B & L. sativa & + & 23.30 \\
\hline $\mathrm{U} 106^{\mathrm{c}}$ & P. tracheiphilum & B & L. sativa & + & 22.94 \\
\hline $\mathrm{U} 331^{\mathrm{c}}$ & P. tracheiphilum & B & L. sativa & + & 22.83 \\
\hline $\mathrm{U} 280^{\mathrm{c}}$ & P. tracheiphilum & B & L. sativa & + & 22.36 \\
\hline $\mathrm{U} 351^{\mathrm{c}}$ & P. tracheiphilum & B & L. sativa & + & 21.72 \\
\hline $\mathrm{U} 216^{\mathrm{c}}$ & P. tracheiphilum & B & L. sativa & + & 21.50 \\
\hline $\mathrm{U} 322^{\mathrm{c}}$ & P. tracheiphilum & B & L. sativa & + & 22.69 \\
\hline $\mathrm{U} 96^{\mathrm{c}}$ & P. tracheiphilum & B & L. sativa & + & 21.95 \\
\hline $\mathrm{U} 134^{\mathrm{c}}$ & P. tracheiphilum & B & L. sativa & + & 22.87 \\
\hline $\mathrm{U} 212^{\mathrm{c}}$ & P. tracheiphilum & B & L. sativa & + & 21.68 \\
\hline $\mathrm{BR} 0128^{\mathrm{b}}$ & P. ultimum & I & NA & + & ND \\
\hline $\mathrm{P} 3^{\mathrm{c}}$ & P. ultimum & I & L. sativa & + & ND \\
\hline $\mathrm{U} 180^{\mathrm{c}}$ & P. ultimum & I & Spinacia oleracea & + & ND \\
\hline $\mathrm{U} 307^{\mathrm{c}}$ & P. ultimum & I & L. sativa & + & ND \\
\hline $\mathrm{U} 316^{\mathrm{c}}$ & P. ultimum & I & L. sativa & + & ND \\
\hline $\mathrm{BR} 0322^{\mathrm{b}}$ & P. violae & I & NA & + & ND \\
\hline LEV $1800^{\mathrm{b}}$ & P. aphanidermatum & A & NA & + & ND \\
\hline $\mathrm{BR} 0122^{\mathrm{b}}$ & P. arrhenomanes & B & NA & + & ND \\
\hline LEV1532b & P. catenulatum & B & NA & + & ND \\
\hline $\mathrm{BR} 0160^{\mathrm{b}}$ & P. conidiophorum & B & NA & + & ND \\
\hline $\mathrm{BR} 0262^{\mathrm{b}}$ & P. conidiophorum & B & NA & + & ND \\
\hline LD15230d & P. dissotocum & B & NA & + & ND \\
\hline $\mathrm{U} 327^{\mathrm{c}}$ & P. helicandrum/prolatum & $\mathrm{H}$ & Daucus carota & + & ND \\
\hline BR0924 & $P$. intermedium & $\mathrm{F}$ & NA & + & ND \\
\hline $\mathrm{U} 209^{\mathrm{c}}$ & P. attrantheridium & $\mathrm{F}$ & L. sativa & + & ND \\
\hline LD19487d & P. irregulare & $\mathrm{F}$ & NA & + & ND \\
\hline U199c & P. irregulare & $\mathrm{F}$ & L. sativa & + & ND \\
\hline $\mathrm{BR} 1031^{\mathrm{b}}$ & P. mопоspermum & B & NA & + & ND \\
\hline $\mathrm{U} 191^{\mathrm{c}}$ & P. oopapillum & B & S. oleracea & + & ND \\
\hline $\mathrm{BR} 1024^{\mathrm{b}}$ & P. salpingophorum & B & NA & + & ND \\
\hline $\mathrm{BR} 0750^{\mathrm{b}}$ & P. salpingophorum & B & NA & + & ND \\
\hline $\mathrm{U} 335^{\mathrm{c}}$ & P. sulcatum & B & D. carota & + & ND \\
\hline $\mathrm{U} 343^{\mathrm{c}}$ & P. sulcatum & B & D. carota & + & ND \\
\hline LD19496 ${ }^{\mathrm{d}}$ & P. sylvaticum & $\mathrm{F}$ & NA & + & ND \\
\hline $\mathrm{U} 262^{\mathrm{c}}$ & P. sylvaticum & $\mathrm{F}$ & D. carota & + & ND \\
\hline $\mathrm{U} 273^{\mathrm{c}}$ & P. sylvaticum & $\mathrm{F}$ & D. carota & + & ND \\
\hline $\mathrm{U} 438^{\mathrm{c}}$ & P. sylvaticum & $\mathrm{F}$ & D. carota & + & ND \\
\hline $\mathrm{BR} 0626^{\mathrm{b}}$ & P. torulosum & B & NA & + & ND \\
\hline $\mathrm{U} 238^{\mathrm{c}}$ & Rhizoctonia solani $A G 1-1 B$ & $\ldots$ & L. sativa & + & ND \\
\hline $\mathrm{SS} 1^{\mathrm{c}}$ & Sclerotinia sclerotiorum & $\ldots$ & L. sativa & + & ND \\
\hline $\mathrm{AE} 1^{\mathrm{c}}$ & Aphanomyces euteiches & $\ldots$ & NA & + & ND \\
\hline $\mathrm{Bc}^{\mathrm{c}}$ & Botrytis cinerea & $\ldots$ & NA & + & ND \\
\hline $\mathrm{BS} 45^{\mathrm{c}}$ & B. squamosa & $\ldots$ & Allium сера & + & ND \\
\hline $\mathrm{U} 196^{\mathrm{c}}$ & Fusarium oxysporum & $\ldots$ & L. sativa & + & ND \\
\hline $\mathrm{U} 596^{\mathrm{c}}$ & F. proliferatum & $\ldots$ & Allium sativum & + & ND \\
\hline $\mathrm{U} 349^{\mathrm{c}}$ & F. solani & $\ldots$ & L. sativa & + & ND \\
\hline LD19236 ${ }^{\mathrm{d}}$ & Phytophthora capcici & $\ldots$ & NA & + & ND \\
\hline $\mathrm{PB} 1^{\mathrm{c}}$ & Plasmodiophora brassicae & $\ldots$ & Brassica rapa & + & ND \\
\hline
\end{tabular}

${ }^{\mathrm{a}}$ ITS $=$ internal transcribed spacer, NA = not available, and ND = not detected.

b Provided by Agriculture and Agri-Food Canada.

${ }^{c}$ Collection and ITS sequencing performed in this study.

${ }^{\mathrm{d}}$ Provided by the Laboratoire de diagnostic en phytoprotection but ITS sequencing performed in this study. 
P. tracheiphilum-specific probe and primer design. In total, 90 ITS sequences (65 obtained during the current study and 25 obtained from GenBank) were aligned using the MAFFT alignment tool available in Geneious V9.1.3. To provide the highest specificity for the assay and the maximum discriminating power between related species, MGB technology was preferred over a conventional TaqMan probe (Kutyavin et al. 2000). Primers and the TaqMan-MGB probe were designed with Primer Express V3.0.1 (Life Technologies, Carlsbad, CA, USA). Primers were designed so that nucleotides specific to $P$. tracheiphilum were located at the $3^{\prime}$ end of the primers and the amplicon was shorter than 200 bp (Bilodeau et al. 2012) (Table 1). The MGB probe designed was labeled at the $5^{\prime}$ end with fluorescein while the $3^{\prime}$ end was labeled with the MGB non-fluorescent quencher (Table 1).

The specificity of the designed assay was evaluated by performing the assay with DNA of 44 isolates of Pythium spp., other fungi, and oomycetes (20 obtained during the current study, 20 obtained from DAOM, and 4 obtained from the Laboratoire de Diagnostic en Phytoprotection) (Table 2). The qPCR assay was performed as described previously with DNA concentration of $1 \mathrm{ng} /$ reaction.

$I C$. To detect and quantify any variation in qPCR efficiency due to the presence of PCR inhibitors, an IC was used as described by Fall et al. (2015). The random nucleotide sequence consisted of a 500-bp double-stranded gBlock (gBlock; IDT DNA Technologies, Coralville, IA, USA). The primers EIPC EIPC100-F and EIPC100-R were used along with the TaqMan probe EIPC100-P labeled at the $5^{\prime}$ end with HEX and with the Zen-Iowa black double quencher at the 3' end. To assess the concentration of IC to be added in the qPCR mixture that does not affect qPCR efficiency, different concentrations of the IC were tested along with a 10 -fold serial dilution of a $P$. tracheiphilum genomic DNA (gDNA)-based standard curve ranging from 300 to 0.003 ng and with a gBlock-based standard curve of $P$. tracheiphilum ITS-2 region ranging from $6 \times 10^{5}$ to $6 \times 10^{\circ}$ copies. The double-stranded gBlock $P$. tracheiphilum ITS-2 region was $50 \mathrm{bp}$ longer than the genomic ITS-2 pathogen region amplified with the 909F, PTMGB-R primers.

Determination of best $q P C R$ conditions. The qPCR assays were conducted in a CFX connect real-time qPCR instrument (Biorad, Mississauga, ON, Canada). Each $25-\mu l$ reaction contained $300 \mathrm{nM}$ each primer (909F, PTMGB-R, EIPC100F, and EIPC100R), $100 \mathrm{nM}$ each probe (PTMGBP and EIPC100P), $0.05 \mathrm{ng}$ of bovine serum albumen, $6 \mathrm{mM}$ additional $\mathrm{MgCl}_{2}, 1 \times$ PerfeCTa qPCR ToughMix without ROX (Quanta Bioscience, Beverley, MA, USA), 600 copies of the IC, and $3 \mu \mathrm{l}$ of target DNA solution. The qPCR cycling conditions were set at $95^{\circ} \mathrm{C}$ for $5 \mathrm{~min}$, followed by 40 cycles at $95^{\circ} \mathrm{C}$ for $15 \mathrm{~s}$ and $62^{\circ} \mathrm{C}$ for $20 \mathrm{~s}$. In each PCR run, a negative control containing only the IC was included to serve as a reference to measure inhibition $\left(\Delta \mathrm{Ct}_{\mathrm{IC}}\right)$.

Validation with artificially and naturally infested soil samples. The sensitivity of the newly developed assay was determined by inoculating organic soil samples with known quantities of $P$. tracheiphilum oospores. To produce oospores, 6-mm plugs of $P$. tracheiphilum isolate U216 were placed on V8 agar ( $200 \mathrm{ml}$ of V8 juice, $3 \mathrm{~g}$ of $\mathrm{CaCO}_{3}$, and $15 \mathrm{~g}$ of agar for 1 liter of media) and incubated at room temperature. After 14 days, the surface of the petri dish was scraped with a sterile spatula and flooded with $10 \mathrm{ml}$ of distilled water. The suspension containing oospores was sieved through four layers of cheesecloth to remove mycelium and other debris. After sieving, oospore concentration was estimated using a hemocytometer and adjusted to 10,000 oospores $/ \mathrm{ml}$. The resulting oospore suspension was inoculated in $10 \mathrm{~g}$ of a sterilized histosol (organic matter content greater than $80 \%$ and $\mathrm{pH}$ 5.8; Les sols Isabelle, St-Michel, QC, Canada) to obtain concentrations of 5,000, 1,000, 500, 100, 50 , and 10 oospores/g of dry soil. The inoculated soils were gently homogenized on a reciprocal shaker (Eberbach, Ann Arbor, MI, USA) and allowed to rest for $48 \mathrm{~h}$. The soil samples were air dried for $48 \mathrm{~h}$ and homogenized thoroughly with a pestle and mortar. In total, $200 \mathrm{mg}$ of inoculated soil was weighed and used for DNA extraction, as described previously. This experiment was conducted four times.
Soil samples collected in 2015, 2016, and 2017 were used for the validation of this assay. Each spring, soil samples were collected from commercial fields before sowing or transplanting. Each 250-g sample were made of five subsamples taken within the first $15 \mathrm{~cm}$ from the soil surface, in a $36-\mathrm{m}^{2}$ quadrat. Soils were air dried for $24 \mathrm{~h}$ and DNA was extracted from $200 \mathrm{mg}$ of soil using the method described above. The DNA samples were assessed in duplicate using the multiplex real-time qPCR assay, as described previously. First, soil samples were collected in the spring at 40 commercial fields with different cropping systems and located in different agricultural production areas of the province of Québec (Table 3). Second, to assess the robustness of the assay, 158 sites were sampled in Napierville County, the most important lettuce production area. When collecting soil samples, lettuce stunt and wilt incidence were evaluated at 44 sampling sites. Each of these 44 sampling quadrats of $36 \mathrm{~m}^{2}$ contained 216 lettuce plants (cultivar Estival) which were evaluated for disease incidence at the 12leaf stage and at harvest. Wilted lettuce plants were torn from the ground to confirm that the observed symptoms could be attributed to $P$. tracheiphilum and to make sure that wilted plants were only counted once. Disease incidence was calculated as cumulative percent diseased plants.

Statistical analysis. Linear regression analyses were used to describe the relationship and best-fit line for $P$. tracheiphilum gDNA (from 300 to $0.003 \mathrm{ng}$ ) and gBlock-based (from $6 \times 10^{\circ}$ to $6 \times 10^{5}$ copies) standard curves with and without the IC and a one-sided $t$ test was used to compare the slopes and intercepts of the regression curves obtained. The sensitivity of the qPCR assay in soil was determined using an analysis of variance (ANOVA). Finally, for the preliminary characterization of the relationship between inoculum density and incidence relationship, a nonlinear model was fitted to the observed data. The statistical analyses were performed using SAS software (version 9.3; SAS Institute, Inc., Cary, NC, USA).

\section{Results}

Pythium sp. from lettuce root and root rhizosphere. Among the 128 samples collected in 2010 and 2011, 125 root samples and 64 soil samples gave a PCR product with the universal primers UNup18S42 and Oom-lo28S-345H and were further tested by DNA array hybridization. Overall, nine Pythium spp. were detected in root samples while only five species were found in soils. $P$. tracheiphilum was by far the most abundant species found in roots, followed by $P$. sylvaticum, $P$. irregulare, $P$. ultimum, and $P$. torulosum (Fig. 1). To a lesser extent, $P$. graminicola, $P$. monospermum, $P$. rostratum, and $P$. violae were found in less than $10 \%$ of the root samples (Fig. 1). Unlike root samples, $P$. irregulare, $P$. sylvaticum, and $P$. ultimum were the most frequently detected species from soil samples, followed by $P$. tracheiphilum and $P$. rostratum (Fig. 1).

Primers and probe specificity and sensitivity. Based on the alignment of the ITS region from the rDNA of 95 Pythium spp., specific primers and probes were designed (Table 1). Neighbor-joining tree analysis of the ITS-2 region showed that $P$. tracheiphilum sequences chosen for the development of the Taqman assay were unique and that $P$. salpinghophorum or its synonym, $P$. conidioporum, had the highest level of sequence homology (Fig. 2). All isolates of $P$. tracheiphilum were amplified with the specific primers and Taqman MGB probe whereas no amplification occurred with the 38 other species tested, including $P$. salpinghophorum or its synonym, $P$. conidioporum (Table 2).

The sensitivity of the qPCR assay was determined with a 10-fold serial dilution of $P$. tracheiphilum gDNA ranging from 300 to 0.003 pg and with a gBlock-based standard curve of $P$. tracheiphilum ITS-2 ranging from $6 \times 10^{5}$ to $6 \times 10^{\circ}$ copies (Fig. 3). For the DNA-based standard curve, the slope of the linear regression was -3.39 and the amplification efficiency of the qPCR was $97.2 \%$ (Fig. 3A). For the amplicon-based standard curve, the slope of the linear regression was -3.47 and the amplification efficiency of the qPCR was $94.2 \%$ (Fig. 3B).

IC. The reaction parameters for the multiplex qPCR assay $(P$. tracheiphilum + IC) were adjusted after the optimization of the simplex 
assay. It was determined that the IC at 600 copies/ $\mu$ l added to the qPCR mix did not interfere with the qPCR efficiency and had cycle threshold (Ct) values ranging from 25.48 to 26.02 when multiplexed. At this IC concentration, the slope of the linear regression for the gDNA-based standard curve was slightly reduced to -3.44 and the amplification efficiency of the qPCR to $95.3 \%$ (Fig. 3A). For the gBlock-based standard curve, the slope of the linear regression was -3.43 and the amplification efficiency of the qPCR was $95.7 \%$ (Fig. 3B).

Validation with inoculated soils. Soil DNA was extracted from sterilized, noninfested muck soil samples inoculated with different concentrations of $P$. tracheiphilum oospores. The linear regression showed a negative correlation between $\mathrm{Ct}$ and log-transformed $P$. tracheiphilum oospore concentration and provided a significant fit of the data $(P<0.001)$, with $R^{2}$ value of 0.98 . The equation of the linear regression was $y=-3.76 x+38.73$ (Fig. 4). Moreover, the ANOVA conducted with four independent replicates showed that there was a significant difference effect of inoculum concentrations $(P<0.0001)$. The $\mathrm{Ct}$ values of the soil standard curves were between 24.4 for 5,000 oospores/g of dry soil and 35.6 for 10 oospores/g of dry soil (Fig. 4). Hence, the detection limit for this assay was set to 10 oospores/g of dry soil.
Validation with naturally infested soils. $P$. tracheiphilum was not detected in soil samples collected from fields where head lettuce had not been produced recently (Table 3 ). Ct values of positive samples ranged from 29.5 to 36.2 , corresponding to inoculum densities from 288.5 to 4.7 oospores/g of dry soil (Table 3). Moreover, an increase in inoculum density was generally correlated with the frequency of head lettuce cropping (Table 3). Among the 158 soil samples collected in commercial lettuce fields, oospore densities varied from 0 to $2 \times 10^{5}$ oospores/g of dry soil (Fig. 5A). Among the latter, $21.2 \%$ of the samples tested had less than 12 oospores/g of dry soil, $44.4 \%$ of the samples had between 12 and 146 oospores/g of dry soil, and $30.0 \%$ of the samples had between 146 and 510 oospores/g of dry soil, while only $4.4 \%$ had more than 510 oospores/g of dry soil (Fig. 5A). Regarding the IC, $\Delta \mathrm{Ct}$ values were under 0.1 for $59.0 \%$ of the samples, under 0.5 for $89.8 \%$ of the samples, and under 1.0 for $96.4 \%$ of the samples (Fig. 5B).

Preliminary characterization of the relationship between disease incidence and inoculum density was evaluated for 44 naturally infested soil samples. Disease incidence ranged from 0 to $50 \%$ while soilborne inoculum concentrations ranged from 0 to $699.5 P$. tracheiphilum oospores/g of dry soil (Fig. 6). Soilborne inoculum density of

Table 3. Detection and quantification of Pythium tracheiphilum by real-time quantitative polymerase chain reaction in soil samples taken from commercial fields with different head lettuce history

\begin{tabular}{|c|c|c|c|c|c|c|}
\hline Soil samples & Year $^{\mathbf{a}}$ & Previous crop & Lettuce crops $(n / N)^{\mathbf{b}}$ & P. tracheiphilum mean $\mathrm{Ct}^{\mathrm{c}}$ & $\mathrm{SD}_{\mathrm{Ct}}^{\mathrm{d}}$ & P. tracheiphilum (oospores/g of soil) \\
\hline 1 & 2015 & Potato & $0 / 6$ & ND & $\ldots$ & 0.0 \\
\hline 2 & 2015 & Potato & $0 / 6$ & ND & $\ldots$ & 0.0 \\
\hline 3 & 2015 & Potato & $0 / 6$ & ND & $\ldots$ & 0.0 \\
\hline 4 & 2015 & Potato & $0 / 6$ & ND & $\ldots$ & 0.0 \\
\hline 5 & 2015 & Potato & $0 / 6$ & ND & $\ldots$ & 0.0 \\
\hline 6 & 2015 & Potato & $0 / 6$ & ND & $\ldots$ & 0.0 \\
\hline 7 & 2015 & Potato & $0 / 6$ & ND & $\ldots$ & 0.0 \\
\hline 8 & 2015 & Soybean & $0 / 6$ & ND & $\ldots$ & 0.0 \\
\hline 9 & 2015 & Soybean & $0 / 6$ & ND & $\ldots$ & 0.0 \\
\hline 10 & 2016 & Spinach & $0 / 7$ & ND & $\ldots$ & 0.0 \\
\hline 11 & 2016 & Grappe & $0 / 7$ & ND & $\ldots$ & 0.0 \\
\hline 12 & 2016 & Grappe & $0 / 7$ & ND & $\ldots$ & 0.0 \\
\hline 13 & 2016 & Grappe & $0 / 7$ & ND & $\ldots$ & 0.0 \\
\hline 14 & 2017 & Carrot & $0 / 8$ & ND & $\ldots$ & 0.0 \\
\hline 15 & 2016 & Spinach & $1 / 7$ & ND & $\ldots$ & 0.0 \\
\hline 16 & 2016 & Spinach & $1 / 7$ & 36.2 & 0.2 & 4.7 \\
\hline 17 & 2016 & Spinach & $1 / 7$ & 35.0 & 0.1 & 9.9 \\
\hline 18 & 2017 & Onion & $2 / 8$ & 34.6 & 1.3 & 12.9 \\
\hline 19 & 2015 & Lettuce & $2 / 6$ & 33.7 & 0.3 & 22.3 \\
\hline 20 & 2015 & Lettuce & $2 / 6$ & 33.1 & 0.1 & 32.0 \\
\hline 21 & 2016 & Shallots & $3 / 7$ & 35.0 & 0.4 & 10.0 \\
\hline 22 & 2016 & Shallots & $3 / 7$ & 34.4 & 0.4 & 14.2 \\
\hline 23 & 2016 & Onion & $4 / 7$ & 36.2 & 0.5 & 4.7 \\
\hline 24 & 2016 & Onion & $4 / 7$ & 35.0 & 0.8 & 10.1 \\
\hline 25 & 2016 & Lettuce & $5 / 7$ & 31.7 & 0.1 & 75.0 \\
\hline 26 & 2016 & Lettuce & $5 / 7$ & 31.2 & 0.1 & 101.2 \\
\hline 27 & 2016 & Lettuce & $5 / 7$ & 31.1 & 0.1 & 107.6 \\
\hline 28 & 2017 & Onion & $6 / 8$ & 31.3 & 0.2 & 94.1 \\
\hline 29 & 2017 & Onion & $6 / 8$ & 31.3 & 0.2 & 97.6 \\
\hline 30 & 2015 & Lettuce & $7 / 6$ & 32.2 & 0.1 & 54.2 \\
\hline 31 & 2015 & Lettuce & $7 / 6$ & 31.5 & 0.5 & 82.7 \\
\hline 32 & 2017 & Lettuce & $7 / 8$ & 30.5 & 0.0 & 152.6 \\
\hline 33 & 2016 & Lettuce & $7 / 7$ & 30.4 & 0.2 & 165.2 \\
\hline 34 & 2017 & Lettuce & $7 / 8$ & 29.4 & 0.2 & 295.6 \\
\hline 35 & 2016 & Lettuce & $8 / 7$ & 30.6 & 0.1 & 146.2 \\
\hline 36 & 2016 & Lettuce & $8 / 7$ & 30.0 & 0.2 & 206.0 \\
\hline 37 & 2017 & Lettuce & $8 / 8$ & 30.0 & 0.0 & 211.1 \\
\hline 38 & 2017 & Lettuce & $8 / 8$ & 29.7 & 0.4 & 260.0 \\
\hline 39 & 2016 & Lettuce & $8 / 7$ & 29.6 & 0.2 & 268.0 \\
\hline 40 & 2017 & Lettuce & $8 / 8$ & 29.5 & 0.1 & 288.5 \\
\hline
\end{tabular}

a Spring sampling year.

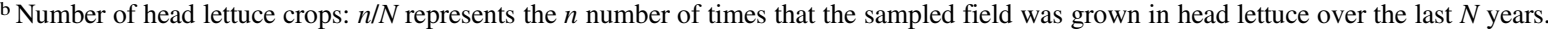

${ }^{\mathrm{c}} \mathrm{Ct}=$ cycle threshold and $\mathrm{ND}=$ not determined.

${ }^{\mathrm{d}} \mathrm{SD}_{\mathrm{Ct}}$ represent the standard deviation on the $\mathrm{Ct}$ values. 
$P$. tracheiphilum in soil was positively correlated with disease incidence $(r=0.764, P<0.0001)$.

\section{Discussion}

Despite the importance of population species composition and diversity for the development of integrated disease management strategies, information on the composition of Pythium communities in vegetable production is scarce. In this study, conducted in muck soils dedicated to the production of vegetable crops, a complex of five Pythium spp. was found in soil collected from the rhizosphere of infected plants ( $P$. irregulare, $P$. sylvaticum, $P$. ultimum, $P$. tracheiphi$l u m$, and $P$. rostratum). In a survey conducted in the Bradford Holland Marsh (Ontario Province, Canada), Kalu et al. (1976) reported five species present in muck soils. However, only $P$. sylvaticum and $P$. irregulare were in common with this study. In soybean fields collected across Ontario, P. ultimum and P. sylvaticum were also found to be predominant (Marchand et al. 2014). Similarly, P. ultimum var. ultimum, $P$. abappressorium, and the $P$. irregulare complex were found to be predominant in soils collected from certified organic fields in the Columbia Basin of central Washington State (Alcala et al. 2016), while P. abappressorium, P. rostratum, and $P$. irregulare group IV were predominant in wheat fields of Washington State (Paulitz and Adams 2003; Schroeder et al. 2006).

In this study, nine Pythium spp. (P. tracheiphilum, P. sylvaticum, $P$. irregulare, $P$. ultimum, $P$. torulosum, $P$. violae, $P$. rostratum, $P$. monospermum, and $P$. graminicola) were found in the roots of infected head lettuce. Unlike the results obtained in soils, P. tracheiphilum was by far the predominant species associated with stunting and wilting of head lettuce. The multiplexing capability of the DNA array approach made possible the screening of about 100 Pythium spp. in each of the many samples we processed. However, despite the polyvalence of the method used for broad surveys, the sensitivity of the DNA macroarray might not be sufficient to detect low levels of soilborne $P$. tracheiphilum inoculum and it is not as quantifiable as qPCR. It was demonstrated that the limit of detection of the DNA array technique can vary when the concentration of the target sequence is low compared with nontarget DNA present in the tested sample (Lievens et al. 2003, 2006; Robideau et al. 2008). Therefore, once $P$. tracheiphilum was identified as the main species colonizing roots, a Taqman-MGB assay was developed for this species.

Pythium stunt caused by $P$. tracheiphilum is an increasing constraint to head lettuce production, especially in muck soils of southwestern Québec. The increasing demand for head lettuce, combined with the limitation of available land suitable for this crop, result in

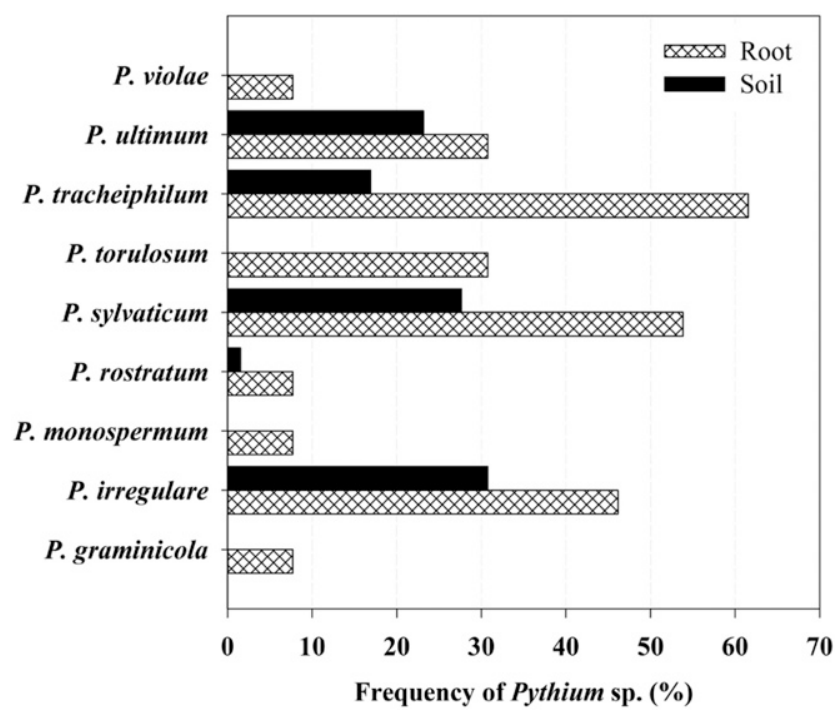

Fig. 1. Frequency distribution of Pythium spp. detected by DNA array hybridization. Samples were collected in southwestern Québec muck soils in 2010 and 2011, with 125 samples from infected root tissues (black bars) and 64 from corresponding soil samples (hatched bars). reduced duration of the crop rotation cycle, increasing the overall mean number of head lettuce crops per year. Most Pythium spp. can survive as oospores under variable conditions (warm, dry, or cold) for a prolonged period of time (Schroeder et al. 2013). As a consequence of the reduced length of crop rotations, soilborne inoculum tends to accumulate and contributes to yield decline (Bennett et al. 2012).

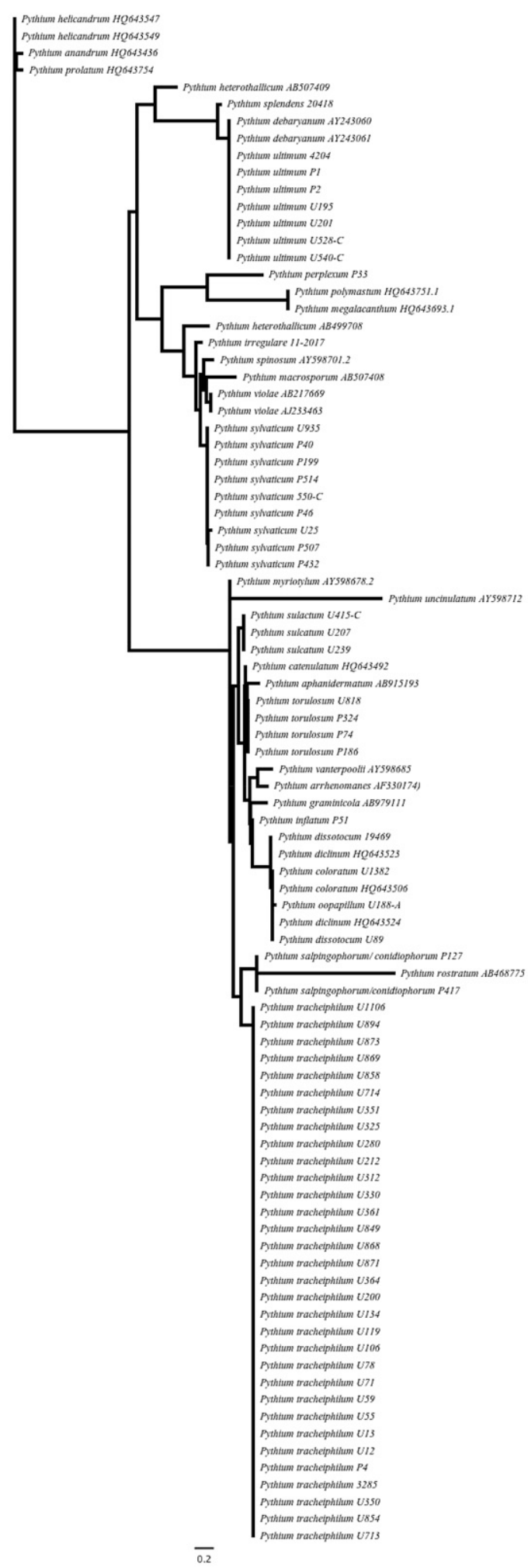

Fig. 2. One of the most parsimonious neighbor-joining trees based on the internal transcribed spacer 2 sequences of 90 Pythium spp. used for the development of the real-time quantitative polymerase chain reaction assay. 
In this study, we described the development of a real-time TaqMan-MGB qPCR assay for the detection and quantification of $P$. tracheiphilum in soil samples. The use of the mitochondrial ITS-1 and -2 regions for the development of molecular makers has proved to be successful for different Pythium spp., including $P$. ultimum (Cullen et al. 2007), $P$. irregulare (Kernaghan et al. 2008), $P$. dissotocum (Le Floch et al. 2007), P. sylvaticum, P. heterothalicum, and $P$. abappressorium (Schroeder et al. 2006). However, the development of diagnostic tools for Pythium spp. represents a challenge, especially for species belonging to the same clade. For P. tracheiphilum (clade B), the nucleotide alignment of the ITS-2 region conducted in this study suggests that $P$. saplingophorum, and its putative synonym $P$. conidiophorum (LéVesque and De Cock 2004), were closely related from a phylogenetic point of view. Nevertheless, Robideau et al. (2011) confirmed in their study that COI and ITS regions were both suitable DNA barcodes for P. tracheiphilum identification. The ITS- 2 region selected for the development of our assay shows a higher level of dissimilarity between $P$. tracheiphilum and the other Pythium spp. than COI. For P. saplingophorum and its putative synonym, $P$. conidiophorum, the level of dissimilarity between their sequences and those of $P$. tracheiphilum ranged from 30.6 to $32.6 \%$. For this assay, the highest level of dissimilarity was allocated to the MGB probe to improve the specificity of the designed assay. This approach was recently used for the development of molecular markers aiming at detecting a broad range of Phytophthora spp. (Bilodeau et al. 2014; Miles et al. 2017). In addition to increased specificity, this approach also enables the development of assays that worked under a wide range of PCR conditions and reduces the risk of false positives.

The dynamic range of the multiplex $P$. tracheiphilum assay was linear over six orders of magnitude while the qPCR efficiency, measured with 10-fold serial dilution of DNA and gBlock standard curves, were $95.3 \%$ and $95.7 \%$, respectively. These results lie within the range of acceptance according to Bustin and Huggett (2017). However, the efficiency of qPCR is often variable. The efficiency of the standard curve obtained from the inoculation of $P$. tracheiphilum oospores in sterilized soil was also linear, with a qPCR efficiency of 85.0\%. For P. ultimum, Cullen et al. (2007) obtained a reaction efficiency of $81.5 \%$, while another study report reaction efficiencies of $91.0 \%$ and above for P. ultimum and P. vexans (Spies et al. 2011). According to Schroeder et al. (2013), there are only a few studies describing TaqMan assays to detect and quantify Pythium spp. in soils. However, among a wide selection of Phytophthora spp., Bilodeau et al. (2014) obtained qPCR efficiencies varying from 91 to $118 \%$, and ranging from 85 to $118 \%$ for Miles et al. (2017).

To circumvent the potential effect of PCR inhibitors, it is common to proceed to a dilution of the DNA samples prior to PCR amplification. However, with this approach, many dilutions may be

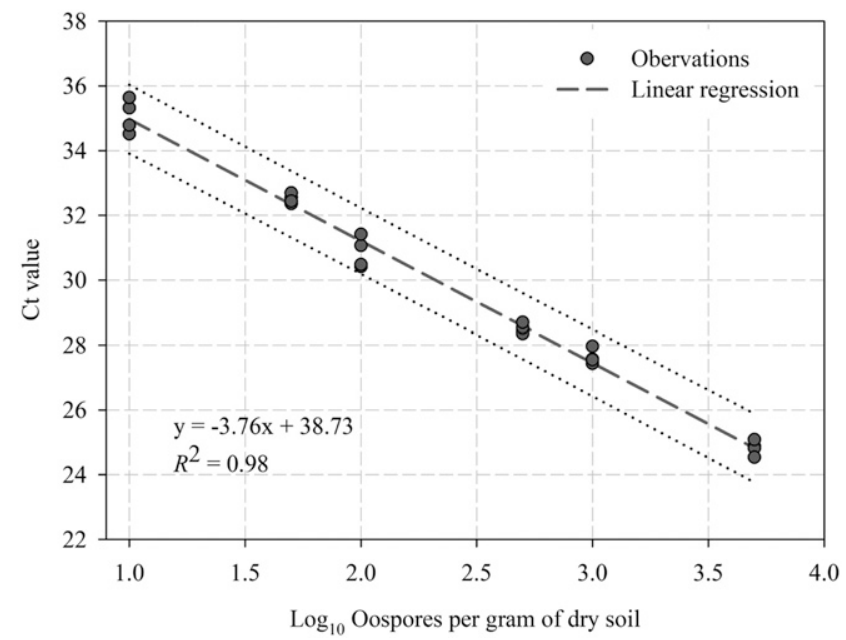

Fig. 4. Linear regression of mean TaqMan-minor groove binder cycle threshold (Ct) value plotted against the $\log _{10}$ of Pythium tracheiphilum oospores obtained from artificial inoculation of sterilized soils.
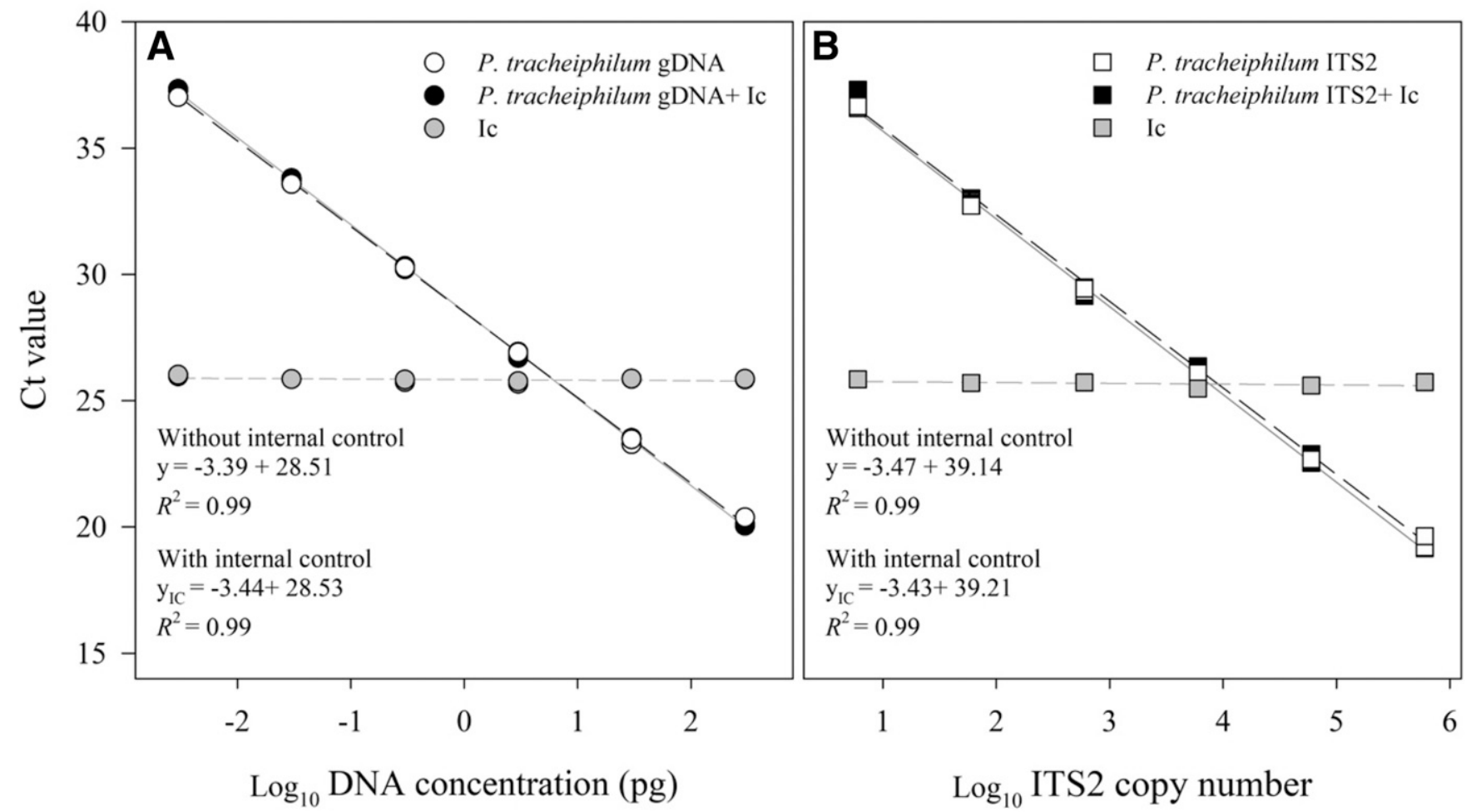

Fig. 3. Standard curves of a Pythium tracheiphilum dilution series with cycle threshold (Ct) plotted against the $\log _{10}$ of $\mathbf{A}$, genomic DNA (gDNA) and B, amplicon copy number with and without internal control $(\mathrm{IC})$ obtained from three independent experiments with two technical replicates in each experiment. White circles and squares represent the amplification without IC while black circles and squares represent the amplification without IC for gDNA and copy number, respectively. Gray circles and squares represent the amplification of the IC when multiplexed with the P. tracheiphilum assay. 
required, increasing the number of samples and reducing the sensitivity of the assay. In real-time qPCR, the presence of these inhibitors may also lead to a reduction of the amplification efficiency, a displacement of the $\mathrm{Ct}$ upward, and an underestimation of the target copy number. Hence, to investigate the effect of PCR inhibitors in a real-time qPCR assay, it is necessary to include an IC that will react similarly to the target to the presence of inhibitors without interfering with the main reaction. The IC included in this assay enabled the validation of each sample tested and allowed limitation of false-negative results. Similarly, this approach was used for assays aimed at the quantification of soilborne and airborne distributed plant pathogens (Bilodeau et al. 2012; Carisse et al. 2009; Deora et al. 2015; Fall et al. 2015). ICs have also been used in DNA extraction buffers, prior to the start of the DNA extraction process, in order to estimate the efficiency of DNA recovery. In their study, Daniell et al. (2012) found that recovery efficiencies ranged from 2.61 to $13.66 \%$ depending, in part, on soil type analyzed. However, in this study, sampled soils belonged to the same classification group and recovery efficiencies were estimated to be fairly constant at approximately $10 \%$ (data not shown).

The main constraint when developing a molecular assay suitable to detect soilborne inoculum concerns the detection limit. Even though the assay was shown to be highly sensitive with pure gDNA, the recovery of $P$. tracheiphilum DNA from oospores present in soil depends on many factors such as sample preparation and presence of qPCR inhibitors. In this study, soils were artificially inoculated with known quantities of $P$. tracheiphilum oospores obtained from pure cultures. The detection limit for the $P$. tracheiphilum multiplexed
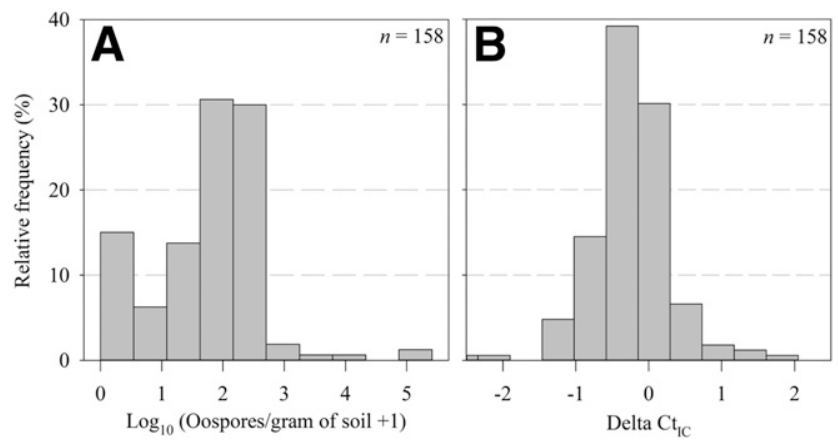

Fig. 5. Frequency distribution of $\mathbf{A}$, the number of oospores of Pythium tracheiphilum obtained from 158 samples taken in commercial fields and $\mathbf{B}$, the difference between the cycle threshold $(\mathrm{Ct})$ value of the internal control (IC) of each sample and the $\mathrm{Ct}$ value of the negative control IC $(\Delta \mathrm{Ct})$.

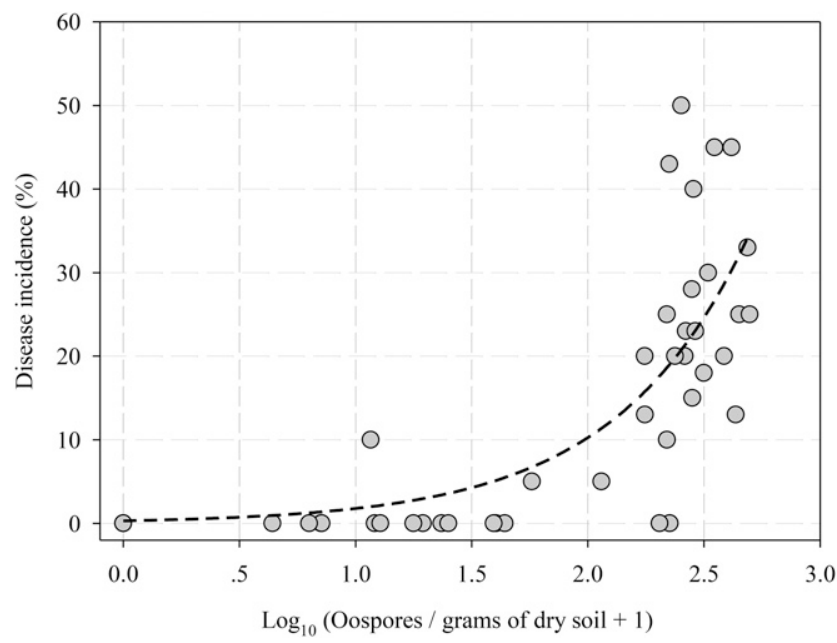

Fig. 6. Relationship between soilborne Pythium tracheiphilum oospore concentration and Pythium root rot disease incidence (DI). Soilborne inoculum density of $P$. tracheiphilum in soil was positively correlated with $\mathrm{DI}(r=0.764, P<0.0001)$.
qPCR assay was established as 10 oospores/g of dry soil, with coefficients of variation less than $2 \%$. In comparison, the detection limit was determined to be between 1 and 50 oospores/g of soil (depending on soil clay content) for Aphanomyces cochlioides (Almquist et al. 2016), 10 oospores/g of soil for A. euteiches (Gangneux et al. 2014), and 20 oospores/g of soil for Phytophthora infestans (Hussain et al. 2005).

Because Pythium tracheiphilum is recognized to have a narrow host range (Berbegal et al. 2012), soil samples taken from fields with no lettuce production history were used for initial validation. As expected, $P$. tracheiphilum was not found in fields where lettuce had never been grown and inoculum density was generally higher with increasing number of lettuce crops per year. Similarly, studies on Verticillium dahliae showed that consecutive lettuce production significantly increases soilborne $V$. dahliae microsclerotia concentrations (Atallah et al. 2011; Short et al. 2015). Pythium root rot incidence was also positively correlated with $P$. tracheiphilum inoculum density. Moreover, a low concentration of $P$. tracheiphilum, above the qPCR detection threshold, was found in soil samples when disease incidence was null or low. These results suggest that the development of a risk index based on inoculum potential measured by real-time qPCR would be possible. The estimation of inoculum potential by real-time qPCR was proven to be successful for several soilborne diseases such as those caused by A. euteiches (Gangneux et al. 2014; Sauvage et al. 2007), A. cochlioides (Almquist et al. 2016), and Plasmodiophora brassicae (Wallenhammar et al. 2012).

Currently, the control of Pythium root rot of lettuce mainly relies on metalaxyl-m as a seed treatment and on systematic applications of cyazofamid prior to seeding or transplantation, but this approach is far from sustainable. The effectiveness of integrated pest management (IPM) strategies and mitigation approaches to reduce the impact of soilborne diseases on yield relies on many factors. However, the first IPM principle suggested for soilborne diseases is to accurately identify the pathogen (Chellemi et al. 2016). Moreover, the success of BCAs as a part of an IPM strategy can be influenced by pathogen species (Weiland 2014) and inoculum density (Narisawa et al. 2005). Hence, the development of this assay to quantify Pythium tracheiphilum inoculum concentration in soils represents the first step toward the development of an effective IPM strategy against lettuce stunt.

\section{Acknowledgments}

We thank the grower members of the PRISME consortium who participated in this project; the Laboratoire d'expertise et de diagnostic en phytoprotection for providing Pythium spp. and pathogenic fungi isolates; Z. R. Djama, J. Couillard, and M. Tremblay for their technical assistance; and all PRISME agronomists, crop specialists, and summer students.

\section{Literature Cited}

Alcala, A. V. C., Paulitz, T. C., Schroeder, K. L., Porter, L. D., Derie, M. L., and du Toit, L. J. 2016. Pythium species associated with damping-off of pea in certified organic fields in the Columbia Basin of central Washington. Plant Dis. 100: 916-925.

Almquist, C., Persson, L., Olsson, Å., Sundström, J., and Jonsson, A. 2016. Disease risk assessment of sugar beet root rot using quantitative real-time PCR analysis of Aphanomyces cochlioides in naturally infested soil samples. Eur. J. Plant Pathol. 145:731-742.

Atallah, Z. K., Hayes, R. J., and Subbarao, K. V. 2011. Fifteen years of verticillium wilt of lettuce in America's salad bowl: A tale of immigration, subjugation, and abatement. Plant Dis. 95:784-792.

Bélanger, R. R., Labbé, C., Lefebvre, F., and Teichmann, B. 2012. Mode of action of biocontrol agents: All that glitters is not gold. Can. J. Plant Pathol. 34 469-478.

Bennett, A. J., Bending, G. D., Chandler, D., Hilton, S., and Mills, P. 2012. Meeting the demand for crop production: The challenge of yield decline in crops grown in short rotations. Biol. Rev. 87:52-71.

Berbegal, M., Álvarez, L. A., Pérez-Sierra, A., and Armengol, J. 2012. Identification of Pythium tracheiphilum as the causal agent of vascular necrosis of endive (Cichorium endivia) in Spain. Phytoparasitica 40:1-4.

Bilodeau, G. J., Koike, S. T., Uribe, P., and Martin, F. N. 2012. Development of an assay for Rapid detection and quantification of Verticillium dahliae in soil. Phytopathology 102:331-343.

Bilodeau, G. J., Martin, F. N., Coffey, M. D., and Blomquist, C. L. 2014 Development of a multiplex assay for genus- and species-specific detection of Phytophthora based on differences in mitochondrial gene order. Phytopathology 104:733-748. 
Blancard, D., Lot, H., and Maisonneuve, B. 2003. Diseases of Lettuces: Identification, Detection and Control. INRA Editions, Paris.

Blok, I., and van der Plaats-Niterink, A. J. 1978. Pythium uncinulatum sp. nov. and P. tracheiphilum pathogenic to lettuce. Neth. J. Plant Pathol. 84:135-147.

Bustin, S., and Huggett, J. 2017. qPCR primer design revisited. Biomol. Detect. Quantif. 14:19-28.

Carisse, O., Tremblay, D. M., Lévesque, C. A., Gindro, K., Ward, P., and Houde, A. 2009. Development of a TaqMan real-time PCR assay for quantification of airborne conidia of Botrytis squamosa and management of Botrytis leaf blight of onion. Phytopathology 99:1273-1280.

Chellemi, D. O., Gamliel, A., Katan, J., and Subbarao, K. V. 2016. Development and deployment of systems-based approaches for the management of soilborne plant pathogens. Phytopathology 106:216-225.

Conway, K. E. 1985. Selective medium for isolation of Pythium spp. from soil. Plant Dis. 69:393-395.

Coplin, D. L., Schmitthenner, A. F., and Bauerle, W. L. 1980. Root of lettuce incited by Pythium polymastum. Plant Dis. 64:63-66.

Cullen, D. W., Toth, I. K., Boonham, N., Walsh, K., Barker, I., and Lees, A. K. 2007. Development and validation of conventional and quantitative polymerase chain reaction assays for the detection of storage rot potato pathogens, Phytophthora erythroseptica, Pythium ultimum and Phoma foveata. J. Phytopathol. 155:309-315.

Daniell, T. J., Davidson, J., Alexander, C. J., Caul, S., and Roberts, D. M. 2012. Improved real-time PCR estimation of gene copy number in soil extracts using an artificial reference. J. Microbiol. Methods 91:38-44.

Deora, A., Gossen, B. D., Amirsadeghi, S., and McDonald, M. R. 2015. A Multiplex qPCR assay for detection and quantification of Plasmodiophora brassicae in soil. Plant Dis. 99:1002-1009.

El-Katatny, M. H., Abdelzaher, H. M. A., and Shoulkamy, M. A. 2006. Antagonistic actions of Pythium oligandrum and Trichoderma harzianum against phytopathogenic fungi (Fusarium oxysporum and Pythium ultimum var. ultimum). Arch. Phytopathol. Plant Prot. 39:289-301.

Fall, M. L., Tremblay, D. M., Gobeil-Richard, M., Couillard, J., Rocheleau, H., Van der Heyden, H., Lévesque, C. A., Beaulieu, C., and Carisse, O. 2015. Infection efficiency of four Phytophthora infestans clonal lineages and DNAbased quantification of sporangia. PLoS One 10:e0136312.

Fessehaie, A., De Boer, S. H., and Lévesque, C. A. 2003. An oligonucleotide array for the identification and differentiation of bacteria pathogenic on potato. Phytopathology 93:262-269.

FAO. 2017. FAOSTAT Statistics Database. Online publication. Food and Agriculture Organization of the United Nations. http://www.fao.org/faostat/ en/\#home

Gangneux, C., Cannesan, M.-A., Bressan, M., Castel, L., Moussart, A., VicréGibouin, M., Driouich, A., Trinsoutrot-Gattin, I., and Laval, K. 2014. A Sensitive assay for rapid detection and quantification of Aphanomyces euteiches in soil. Phytopathology 104:1138-1147.

Hall, G. 1989. Unusual or interesting records of plant pathogenic oomycetes. Plant Pathol. 38:604-611.

Hendrix, F., and Campbell, W. A. 1973. Pythiums as plant pathogens. Annu. Rev. Phytopathol. 11:77-98.

Hussain, S., Lees, A. K., Duncan, J. M., and Cooke, D. E. L. 2005. Development of a species-specific and sensitive detection assay for Phytophthora infestans and its application for monitoring of inoculum in tubers and soil. Plant Pathol. 54:373-382.

Jeffers, S. N., and Martin, S. B. 1986. Comparison of two media selective for Phytophthora and Pythium species. Plant Dis. 70:1038-1043.

Kalu, N. N., Sutton, J. C., and Vaartaja, O. 1976. Pythium spp. associated with root dieback of carrot in Ontario. Can. J. Plant Sci. 56:555-561

Kernaghan, G., Reeleder, R. D., and Hoke, S. M. T. 2008. Quantification of Pythium populations in ginseng soils by culture dependent and real-time PCR methods. Appl. Soil Ecol. 40:447-455.

Kilany, M., Ibrahim, E. H., Al Amry, S., Al Roman, S., and Siddiqi, S. 2015. Microbial suppressiveness of Pythium damping-off diseases. Pages 187-206 in: Organic Amendments and Soil Suppressiveness in Plant Disease Management. M. K. Meghvansi and A. Varma, eds. Springer International Publishing, Cham.

Kumar, S., Ray, E. J., Davison, E. M., Cunnington, J. H., and de Alwis, S. 2007. First record of Pythium tracheiphilum associated with lettuce wilt and leaf blight in Australia. Australas. Plant Dis. Notes 2:7-9.

Kutyavin, I. V., Afonina, I. A., Mills, A., Gorn, V. V., Lukhtanov, E. A., Belousov, E. S., Singer, M. J., Walburger, D. K., Lokhov, S. G., Gall, A. A., Dempcy, R., Reed, M. W., Meyer, R. B., and Hedgpeth, J. 2000. 3'-Minor groove binderDNA probes increase sequence specificity at PCR extension temperatures. Nucleic Acids Res. 28:655-661.

Le Floch, G., Tambong, J., Vallance, J., Tirilly, Y., Lévesque, A., and Rey, P. 2007. Rhizosphere persistence of three Pythium oligandrum strains in tomato soilless culture assessed by DNA macroarray and real-time PCR. FEMS Microbiol. Ecol. 61:317-326.

Lévesque, A. C., and De Cock, A. W. A. M. 2004. Molecular phylogeny and taxonomy of the genus Pythium. Mycol. Res. 108:1363-1383.

Lievens, B., Brouwer, M., Vanachter, A. C. R. C., Cammue, B. P. A., and Thomma, B. P. H. J. 2006. Real-time PCR for detection and quantification of fungal and oomycete tomato pathogens in plant and soil samples. Plant Sci. $171: 155-165$.
Lievens, B., Brouwer, M., Vanachter, A. C. R. C., Lévesque, C. A., Cammue, B. P A., and Thomma, B. P. H. J. 2003. Design and development of a DNA array for rapid detection and identification of multiple tomato vascular wilt pathogens. FEMS Microbiol. Lett. 223:113-122.

Lumsden, R. D., Ayers, W. A., and Dow, R. L. 1975. Differential isolation of Pythium species from soil by means of selective media, temperature, and $\mathrm{pH}$. Can. J. Microbiol. 21:606-612.

Lumsden, R. D., and Locke, J. C. 1989. Biological control of damping-off caused by Pythium ultimum and Rhizoctonia solani with Gliocladium virens in soilless mix. Phytopathology 79:361-366.

Marchand, G., Chen, Y., Berhane, N. A., Wei, L., Lévesque, C. A., and Xue, A. G. 2014. Identification of Pythium spp. from the rhizosphere of soybeans in Ontario, Canada. Can. J. Plant Pathol. 36:246-251.

Matta, A. 1965. Una malattia della lattuga prodotta da una nuova specie di Pythium. Phytopathol. Mediterr. 4:48-53.

Miles, T. D., Martin, F. N., Robideau, G. P., Bilodeau, G. J., and Coffey, M. D. 2017. Systematic development of Phytophthora species-specific mitochondrial diagnostic markers for economically important members of the genus. Plant Dis. 101:1162-1170.

Múnera, J. D. C., and Hausbeck, M. K. 2015. Integrating host resistance and plant protectants to manage Pythium root rot on geranium and snapdragon HortScience 50:1319-1326.

Narisawa, K., Shimura, M., Usuki, F., Fukuhara, S., and Hashiba, T. 2005. Effects of pathogen density, soil moisture, and soil $\mathrm{pH}$ on biological control of clubroot in Chinese cabbage by Heteroconium chaetospira. Plant Dis. 89:285-290.

Nordskog, B., Nærstad, R., Herrero, M. L., Sundheim, L., and Hermansen, A 2008. Fungal pathogens in Norwegian lettuce fields. Acta Agric. Scand. Sect. B. 58:230-235.

Olson, S. 2015. An analysis of the biopesticide market now and where it is going Outlooks Pest Manage. 26:203-206.

Paulitz, T. C., and Adams, K. 2003. Composition and distribution of Pythium communities in wheat fields in Eastern Washington state. Phytopathology 93 867-873.

Paulitz, T. C., Ahmad, J. S., and Baker, R. 1990. Integration of Pythium nunn and Trichoderma harzianum isolate T-95 for the biological control of Pythium damping-off of cucumber. Plant Soil 121:243-250.

Robideau, G. P., Caruso, F. L., Oudemans, P. V., McManus, P. S., Renaud, M. A., Auclair, M. E., Bilodeau, G. J., Yee, D., Désaulniers, N. L., DeVerna, J. W., and Lévesque, C. A. 2008. Detection of cranberry fruit rot fungi using DNA array hybridization. Can. J. Plant Pathol. 30:226-240.

Robideau, G. P., De Cock, A. W. A. M., Coffey, M. D., Voglmayr, H., Brouwer, H., Bala, K., Chitty, D. W., Désaulniers, N., Eggertson, Q. A., Gachon, C. M. M., Hu, C.-H., Küpper, F. C., Rintoul, T. L., Sarhan, E., Verstappen, E. C. P., Zhang, Y., Bonants, P. J. M., Ristaino, J. B., and Lévesque, C. A. 2011. DNA barcoding of oomycetes with cytochrome c oxidase subunit I and internal transcribed spacer. Mol. Ecol. Resour. 11:1002-1011.

Sauvage, H., Moussart, A., Bois, F., Tivoli, B., Barray, S., and Laval, K. 2007. Development of a molecular method to detect and quantify Aphanomyces euteiches in soil. FEMS Microbiol. Lett. 273:64-69.

Schroeder, K. L., Martin, F. N., de Cock, A. W. A. M., Lévesque, C. A., Spies, C F. J., Okubara, P. A., and Paulitz, T. C. 2013. Molecular detection and quantification of Pythium species: Evolving taxonomy, new tools, and challenges. Plant Dis. 97:4-20.

Schroeder, K. L., Okubara, P. A., Tambong, J. T., Lévesque, C. A., and Paulitz, T. C. 2006. Identification and quantification of pathogenic Pythium spp. from soils in Eastern Washington using real-time polymerase chain reaction. Phytopathology 96:637-647.

Short, D. P. G., Sandoya, G., Vallad, G. E., Koike, S. T., Xiao, C.-L., Wu, B.-M., Gurung, S., Hayes, R. J., and Subbarao, K. V. 2015. Dynamics of Verticillium species microsclerotia in field soils in response to fumigation, cropping patterns, and flooding. Phytopathology 105:638-645.

Spies, C. F. J., Mazzola, M., and McLeod, A. 2011. Characterisation and detection of Pythium and Phytophthora species associated with grapevines in South Africa. Eur. J. Plant Pathol. 131:103-119.

Statistics Canada. 2017. Area, production and farm gate value of vegetables. Table 32-10-0365-01 (formerly CANSIM 001-0013). Online publication. https://www150.statcan.gc.ca/t1/tbl1/en/tv.action?pid=3210036501

Tambong, J. T., de Cock, A. W. A. M., Tinker, N. A., and Lévesque, C. A. 2006 Oligonucleotide array for identification and detection of Pythium species. Appl. Environ. Microbiol. 72:2691-2706.

Wallenhammar, A. C., Almquist, C., Söderström, M., and Jonsson, A. 2012. Infield distribution of Plasmodiophora brassicae measured using quantitative real-time PCR. Plant Pathol. 61:16-28.

Weiland, J. E. 2014. Pythium species and isolate diversity influence inhibition by the biological control agent Streptomyces lydicus. Plant Dis. 98:653-659.

White, T. J., Bruns, T., Lee, S., and Taylor, J. 1990. Amplification and direct sequencing of fungal ribosomal RNA genes for phylogenetics. Pages 315-322 in: PCR Protocols: A Guide to Methods and Applications. M. A. Innis, D. H. Gelfand, J. J. Sninsky, and T. J. White, eds. Academic Press, San Diego, CA.

Yuan, W. M., and Crawford, D. L. 1995. Characterization of Streptomyces lydicus WYEC108 as a potential biocontrol agent against fungal root and seed rots. Appl. Environ. Microbiol. 61:3119-3128. 